\title{
Photoluminescence Properties of Azo-Containing Schiff Bases Metal Complexes
}

\author{
Mesut İKIZ ${ }^{1}$, Gökhan CEYHAN ${ }^{2}$, Esin İSPIR ${ }^{1}$ \\ ${ }^{1}$ Department of Chemistry, Kahramanmaraş Sütçü İmam University, Kahramanmaraş, 46050-9, Turkey \\ ${ }^{2}$ Research and Development Centre for University-Industry-Public Relations, Kahramanmaras, Sütçü İmam \\ University, 46100, Kahramanmaras, Turkey
}

\begin{abstract}
The Schiff base ligand containing -N=N- group, 4-((E)-(4-bromophenyl)diazenyl)-2-((E)(phenylimino)methyl)phenol $\left(\mathrm{L}^{1} \mathrm{H}\right)$ (Fig. 1), and its $\mathrm{Co}^{\mathrm{II}}, \mathrm{Cu}^{\mathrm{II}}, \mathrm{Ni}^{\mathrm{II}}, \mathrm{Zn}^{\mathrm{II}}$ and $\mathrm{Fe}^{\mathrm{III}}$ complexes have been prepared and characterized in previous study. According to analytical, UV-visible and IR data, the metal complexes are formed by coordination of the $\mathrm{N}, \mathrm{O}$ atoms of the ligands and metal:ligand ratio was found to 1:2 for all the complexes. In this study, photoluminescence properties of $\mathrm{L}^{1} \mathrm{H}$ and its metal complexes were investigated.
\end{abstract}

Keywords: Schiff Base complexes; azo compounds, photoluminescence

\section{Azo Grubu İçeren Schiff Baz Metal Komplekslerinin Fotolüminesans Özellikleri}

ÖZET: Daha önceki çalışmada 4-((E)-(4-bromophenyl)diazenyl)-2-((E)-(phenylimino)methyl)phenol $\left(\mathrm{L}^{1} \mathrm{H}\right)$ ligandı ve bu ligamndın $\mathrm{Co}^{\mathrm{II}}, \mathrm{Cu}^{\mathrm{II}}$, $\mathrm{Ni}^{\mathrm{II}}, \mathrm{Zn}^{\mathrm{II}}$ ve $\mathrm{Fe}^{\mathrm{III}}$ komplekslerinin sentezi ve karakterizasyonu yapılmış olup komplekslerin metal:ligand oranı 1:2 olacak şekilde oluştuğu gözlenmiştir. $\mathrm{Bu}$ çalışmada sentezi ve karakterizasyonu yapılan ligand ve komplekslerinin fotolüminesans özellikleri incelenmiş̧ir.

Anahtar Kelimeler: Schiff bazı kopmleksleri, azo bileşikleri, fotolüminesans

\section{INTRODUCTION}

Among the various ligands, Schiff base ligands have significant importance because Schiff base ligands are potentially capable of forming stable complexes with metal ions [1]. By attaching donor atoms of Schiff bases, they can coordinate various metals and stabilize them in different oxidation states; such complexes are used as catalysts in many important processes [2, 3]. The $\mathrm{N}=\mathrm{N}$ bonds in azo compounds are good electron/hydrogen acceptors [4]. The molecule bears the azoimine $(-\mathrm{N}=\mathrm{N}-\mathrm{C}=\mathrm{N}-)$ functional group, and is an efficient p-acid system for stabilization of low oxidation state metal ions [5]. Synthesis of metal complexes with luminescence properties has attracted much attention in recent years due to their importance in designing sensors and optical materials [6]. Azo compounds and their complexes are of interest for application in detection of ions in solution. Although, a few azo ligands have been utilised as chemosensors for anions and cations [7-15] but there are scarcity of luminescent metal complexes incorporating azo ligands which can act as efficient sensors for anions. Metal complexes of Schiff bases have been extensively studied at scientific applications as catalysts due to their attractive chemical and physical properties.
In our previous study, the synthesis and characterization of $\mathrm{L} 1 \mathrm{H}$ and its complexes were done [16]. Ligand and complex structures were confirmed by, elemental analysis, FTIR, 1H-, 13C- NMR, and UV/Vis spectroscopy, mass spectrometry, thermal analysis, molar conductivity. Single-crystal X-ray analysis were performed for ligand $\left(\mathrm{L}^{1} \mathrm{H}\right)$ (Figure 3 ) and its $\mathrm{Zn}$ complex $\left(\mathrm{Zn}\left(\mathrm{L}^{1}\right)_{2}\right)$ (Figure 4). The analytical data shows that the ratio of metal to ligand in the mononuclear Schiff Base complexes is 1:2.

Due to the importance of the various properties of Schiff base metal complexes, we herein reported the luminescence properties of $\mathrm{L}^{1} \mathrm{H}$ and its metal complexes.

\section{EXPERIMENTAL}

\subsection{Materials and measurements}

The single-photon fluorescence spectra of the ligand $\left(\mathrm{H}^{1} \mathrm{~L}\right)$ and their metal complexes (Cu(II), $\mathrm{Co}(\mathrm{II})$, $\mathrm{Ni}(\mathrm{II}), \mathrm{Zn}(\mathrm{II})$ and $\mathrm{Fe}(\mathrm{III})$ ) were collected on a Perkin Elmer LS55 luminescence spectrometer. All the samples were prepared in spectrophotometric grade solvents and analyzed in a $1 \mathrm{~cm}$ optical path quartz cuvette. The solution concentrations of the ligand and complexes in DMF solvents were $4.8 \times 10^{-5} \mathrm{~mol} \mathrm{~L}-1$. 
The different concentrations studies were done in the $1 \times 10^{-3}-1 \times 10^{-7} \mathrm{M}$ range and in the DMF solution.

\subsection{Synthesis of bromophenyl)diazenyl)-2- hydroxybenzaldehyde}

(E)-5-((4-bromophenyl)diazenyl)-2hydroxybenzaldehyde was prepared according to the literature method [17].

\subsection{Synthesis of bromophenyl)diazenyl)-2-((E)- (phenylimino)methyl)phenol $\left(\mathbf{L}^{1} \mathbf{H}\right)$ \\ 4-((E)-(4-}

4-((E)-(4-bromophenyl)diazenyl)-2-((E)(phenylimino)methyl)phenol (L1H) (Figure 1) was synthesized as follow; $10 \mathrm{mmol}$ (3.05 g) of (E)-5-((4bromophenyl)diazenyl)-2-hydroxybenzaldehyde and 10 mmol (0.93 g) of aniline were condensed by refluxing in $70 \mathrm{~cm} 3$ of absolute ethanol for $3 \mathrm{~h}$. The solution was left at room temperature. 4-((E)-(4-bromophenyl)diazenyl)2-((E)-(phenylimino)methyl)phenol was obtained as orange micro crystals; the micro crystals were filtered off, washed with $10 \mathrm{~cm} 3$ of absolute ethanol and then recrystallized from DMF.

\subsection{General procedure for the synthesis of metal complexes}

L1H (20 mmol) dissolved in $40 \mathrm{~cm} 3$ absolute $\mathrm{EtOH}$ was mixed with $10 \mathrm{mmol} \mathrm{Cu}(\mathrm{Ac})_{2} \cdot \mathrm{H}_{2} \mathrm{O}$ or $\mathrm{Co}(\mathrm{Ac})_{2} \cdot 4 \mathrm{H}_{2} \mathrm{O}$ in $20 \mathrm{~cm} 3 \mathrm{EtOH}$. The stirred mixture was refluxed for $24 \mathrm{~h}$, then evaporated to $15-20 \mathrm{~cm} 3$ in vacuum and left to cool to room temperature. The compounds were precipitated after adding $5 \mathrm{~cm} 3 \mathrm{EtOH}$. The products were filtered in vacuum, washed with a small amount of $\mathrm{MeOH}$ and water. $\mathrm{Zn}\left(\mathrm{L}^{1}\right)_{2}$ recrystallized from DMF. The products are soluble in solvents such as $\mathrm{CHCl} 3, \mathrm{DMF}$ and DMSO.

\section{Result and Discussion}

\subsection{Synthesis of the compounds}

The Schiff base ligand, $\mathrm{L}^{1} \mathrm{H}$ was prepared by the condensation of (E)-5-((4-bromophenyl)diazenyl)-2hydroxybenzaldehyde with aniline, (1:1 molar ratio) in EtOH as shown in Fig. 1. The level of the purity of the ligand was checked by T.L.C. on silica gel-coated plates. CoII, CuII, NiII, ZnII and FeIII complexes of L1H were prepared.

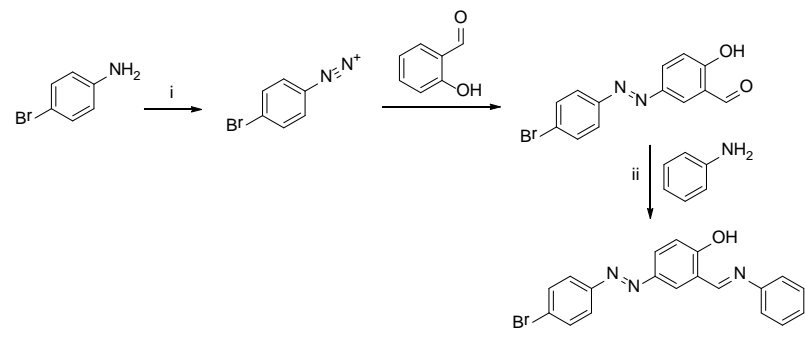

$L^{1} \mathrm{H}$

i. $\mathrm{HCl} / \mathrm{NaNO}_{2}$, salicylaldehyde, $0-5{ }^{\circ} \mathrm{C}$ and (ii) Ethanol, $3 \mathrm{~h}$, reflux.

Figure 1. General sythesis of azo-containing ligand.

The ligand is stable at room temperature and soluble in common organic solvents such as EtOH, $\mathrm{MeOH}, \mathrm{DMF}$ and $\mathrm{CH}_{2} \mathrm{Cl}_{2}$. The complexes are also stable at room temperature. The complexes have oxygen and nitrogen atoms as $\pi$ donors and the metal ions allow $\pi$ electronic delocalization as shown in Figure. 2.
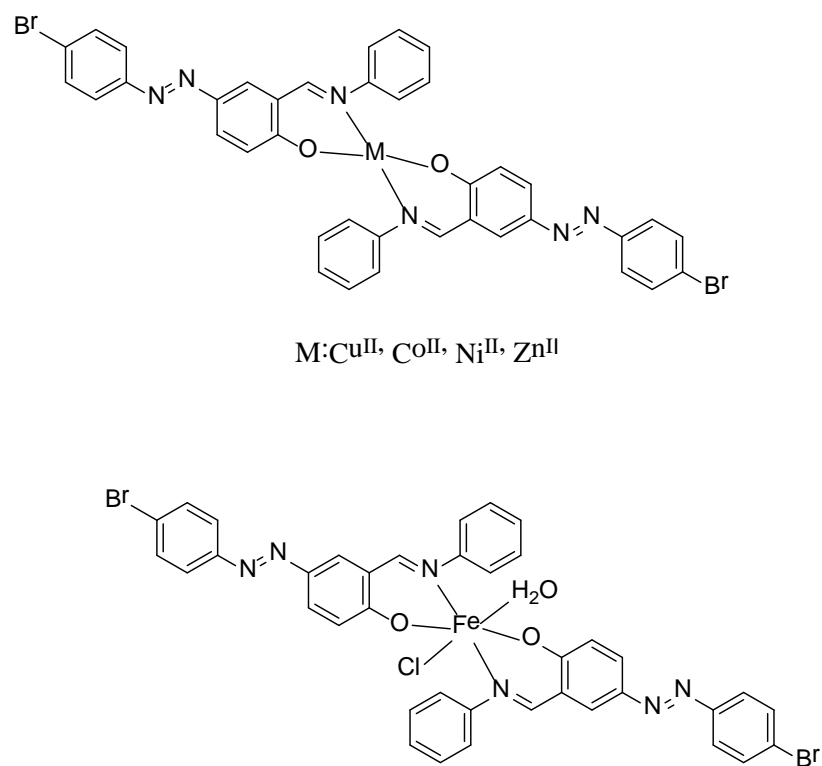

Figure 2. Proposed structures of metal complexes

The structures of the complexes were further characterized by FTIR, UV-visible spectra and elemental analyses. The experimental elemental analyses results of the complexes are in good harmony with the theoretical values. The data show the complexation ratio of formulae $\left[\mathrm{M}(\mathrm{L})_{2}\right.$ ] is $1: 2$ [Metal : Ligand]. Single crystals of $\mathrm{L} 1 \mathrm{H}$ which is shown in Figure 3 and was grown from DMF solutions by slow evaporation. 


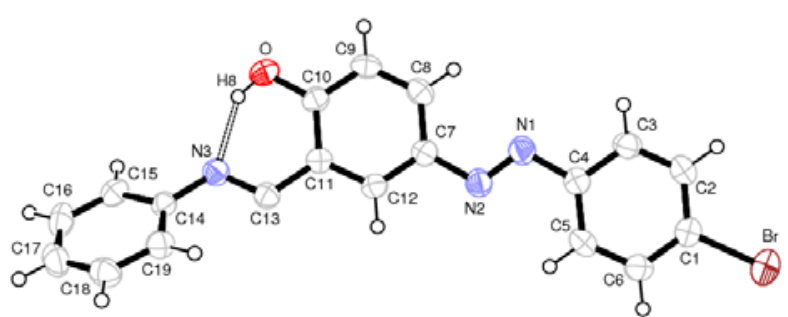

Figure 3. The molecular structure of L1H ligand, with atomic numbering scheme. The thermal ellipsoids are drawn at the $50 \%$ probability level. Dashed lines indicate the intramolecular hydrogen bond.

Also single crystals of $\mathrm{Zn}$ complex which is shown in Figure 4 and was grown from DMF solutions by slow evaporation too.

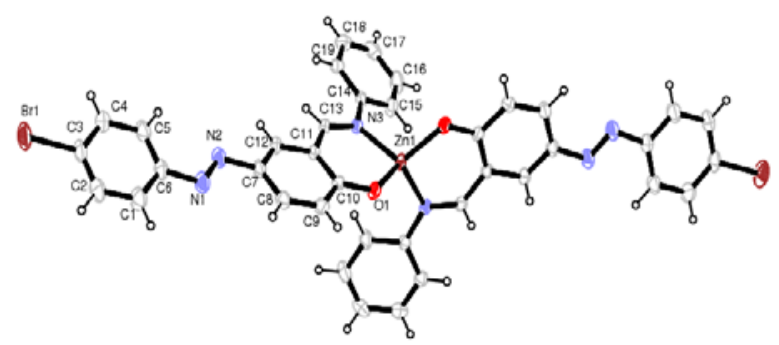

Figure 4. The molecular structure of complex $\left(\mathrm{Zn}\left(\mathrm{L}^{1}\right)_{2}\right)$, with atomic numbering scheme. The thermal ellipsoids are drawn at the 50\% probability level.

\subsection{The effect of different solvent on the photoluminescence properties of the Schiff base ligands}

The photoluminescence propertiesof the ligand $\left(\mathrm{L}_{1} \mathrm{H}\right)$ and their metal complexes (Cu(II), $\mathrm{Co}(\mathrm{II}), \mathrm{Ni}(\mathrm{II})$, $\mathrm{Zn}(\mathrm{II})$ and $\mathrm{Fe}(\mathrm{III})$ ) were studied in DMF solvent using $1 \times 10^{-3}-1 \times 10^{-7}$ solutions and obtained data are given in Table 1. At room temperature, the ligand and metal complexes exhibit similar emission spectra in the Uvvis region. The emission and excitation spectra of the ligand and metal complexes in different concentrations are shown in Figure 5.

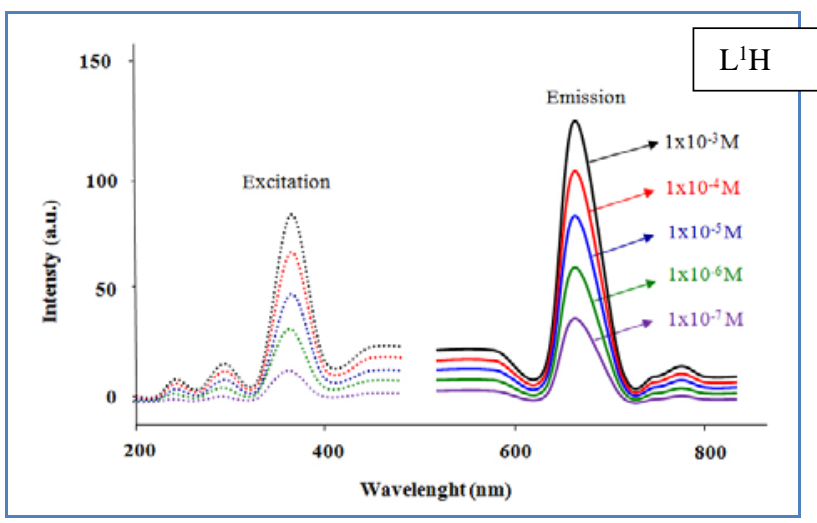

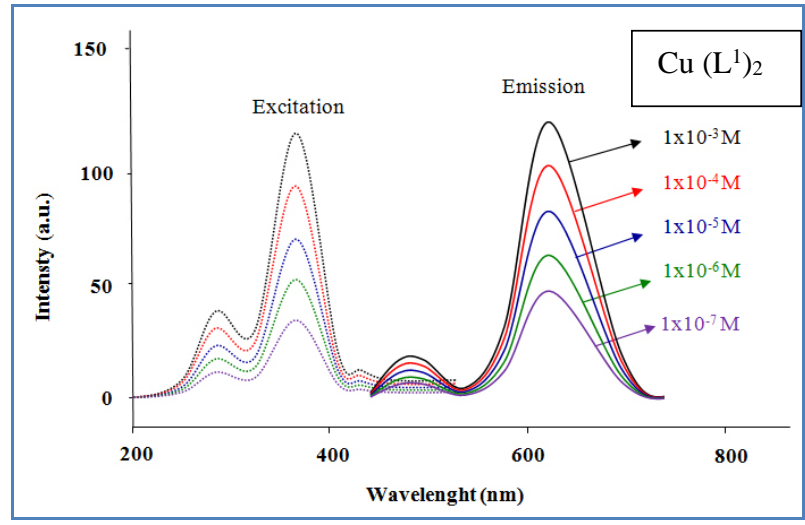
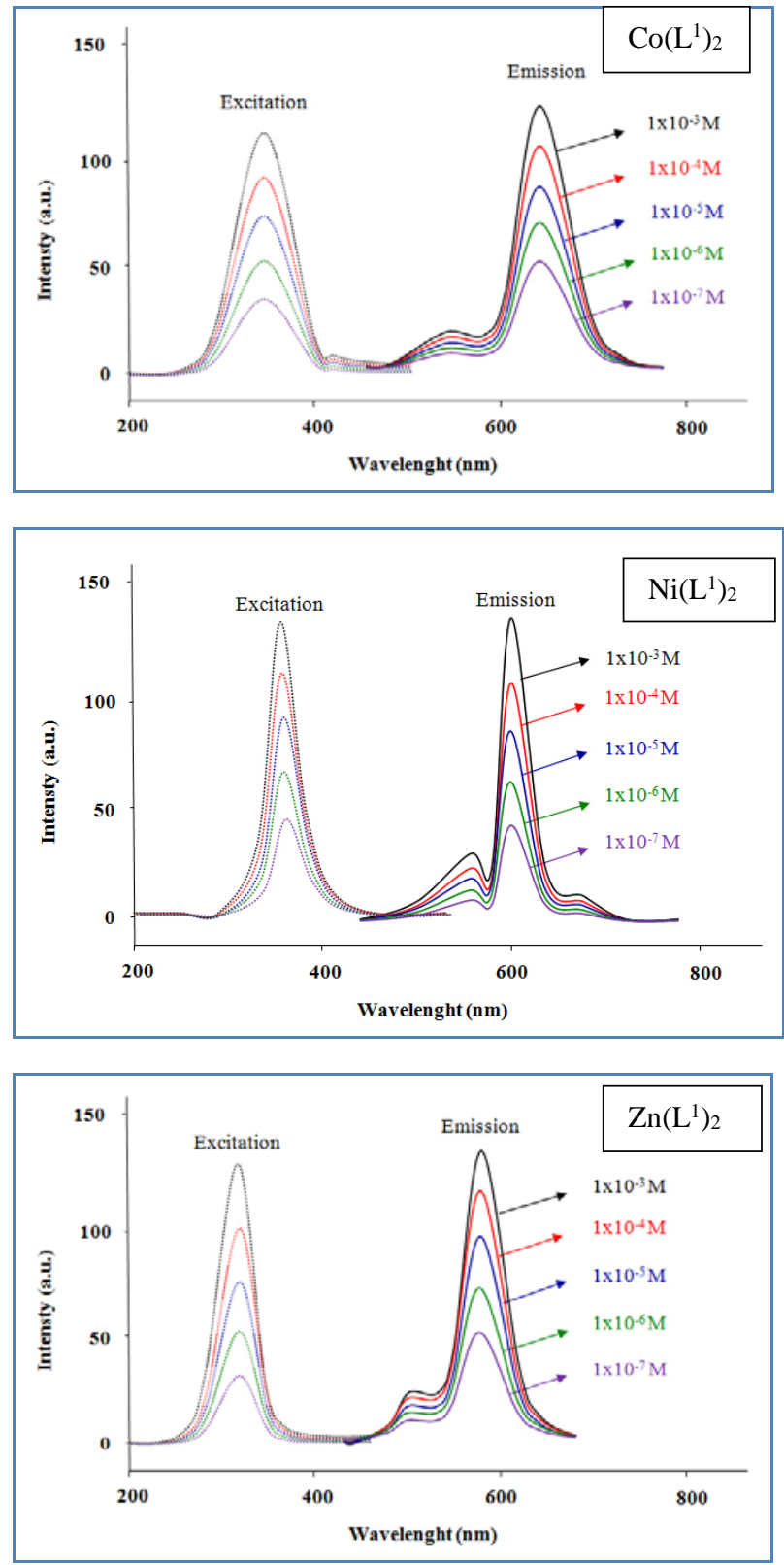


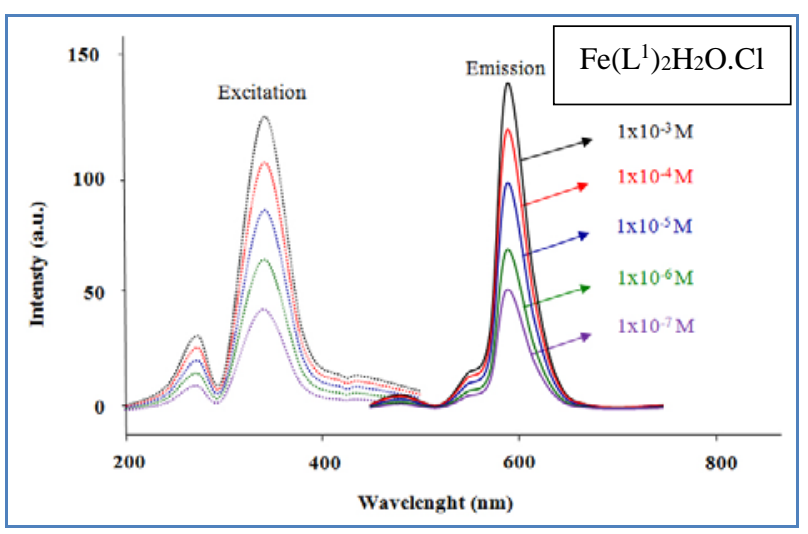

Figure 5. Photochemical specta of $\mathrm{L} 1 \mathrm{H}$ and its metal complexes in different concentrations.

The spectra of the ligand show one emission band in the 680-684 nm range shorter wavelength (SW) region in $1 \times 10^{-3} \mathrm{M}$ concentration and the other in the 680-684 nm range longer wavelength (LW) region. The photoluminescence emission peaks of the ligand (L1H) apparently produce red shift with the introduction of the accepting and donating electron groups such as $-\mathrm{OH}$ and $\mathrm{Br}$. As shown also from Table 1, the introduction of the electron donating groups by mesomeric and inductive effects causes the fluorescence characteristic emission peaks of the ligand to red-shift in the range of $5 \mathrm{~nm}$. The reason is that the electron density of the $\mathrm{OH}-$ groub is increased with the unpaired electron pair effect. The ligand with hydroxyl and brom substituents possesses $\mathrm{p} \rightarrow \pi$ conjugation that can increase their photoluminescence emission intensity [18].

The excitation spectra of the ligand and their metal complexes was investigated in DMF and different concentrations $\left(1 \times 10^{-3}-1 \times 10^{-7}\right)$ obtained data are given in Table 1.

Table 1. UV-visabsorption, emission and excitation spectral data of ligand and their metal complexes.

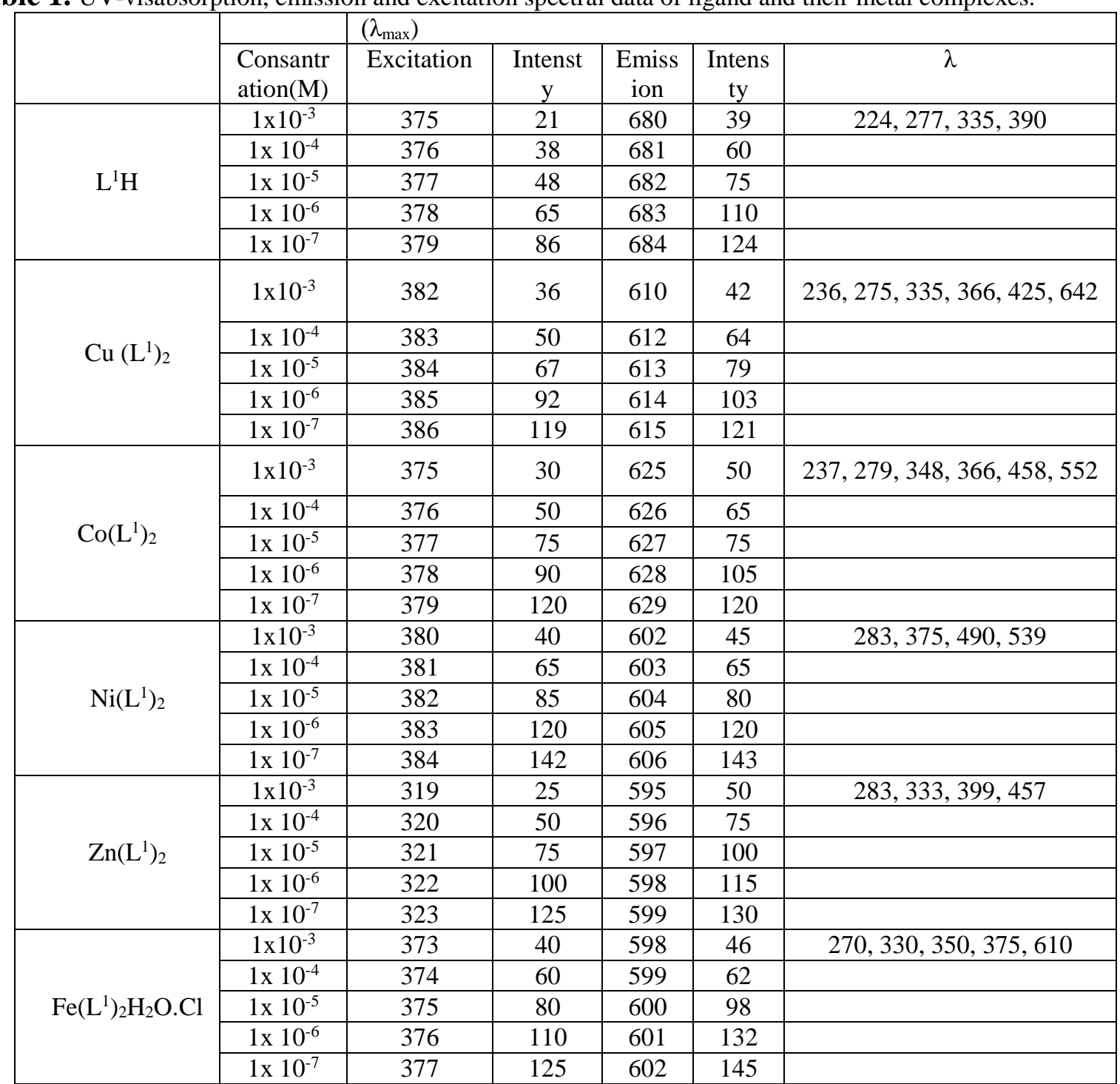


The spectra of the ligand are given in Figure 5 Similar properties were shown also for excitation peaks of the metal complexes. In the $1.0 \times 10^{-3} \mathrm{M}$ concentration, the ligands have highest excitation peaks in the 319-386 $\mathrm{nm}$ range. In the $1.0 \times 10^{-7} \mathrm{M}$ concentration, the excitation peaks of the ligands have both lowest intensity and also shift to the lower regions (319 nm).

\section{Conclusions}

Photoluminescence properties of the schiff base ligand containing $-\mathrm{N}=\mathrm{N}-$ group, 4-((E)-(4bromophenyl)diazenyl)-2-((E)-

(phenylimino)methyl)phenol $\left(L^{1} H\right)$ and its $\mathrm{Co}^{\mathrm{II}}, \mathrm{Cu}^{\mathrm{II}}$, $\mathrm{Ni}^{\mathrm{II}}, \mathrm{Zn}^{\mathrm{II}}$ and $\mathrm{Fe}^{\mathrm{III}}$ complexes prepared studied.

According to the analytical and IR data, the metal complexes are formed by the coordination of $N, O$ atoms of the ligands.

The photoluminescence studies showed that, the ligand with hydroxyl and brom substituents possesses $\mathrm{p} \rightarrow \pi$ conjugation that can increase their photoluminescence emission intensity.

\section{Kaynaklar}

[1]. Shaghaghi, Z., (2014), "Synthesis, structure and photoluminescence properties of functionalized azoimine ligands and their nickel complexes", Spectrochim Acta A, 131, 67.

[2]. Atabey, H., Findik, E., Sari, H., Ceylan, M., (2014), "Comparison of chelating ability of NO-, NS-, ONS-, and ONO-type Schiff base derivatives and their stability constants of Bis-complexes with copper(II)”, Turk J Chem., 38(1), 109.

[3]. Huang, D. X., Wang, C. X., Song, Y. B., (2013), "Immobilized complexes of the salen Schiff's base with metal as oxidation catalysts”, Russ J Gen Chem., 83(12), 2361.

[4]. Farhadi. S., Sepahvand, S., (2010), "Na4W10O32/ZrO2 nanocomposite prepared via a sol-gel route: A novel, green and recoverable photocatalyst for reductive cleavage of azobenzenes to amines with 2-propanol”, J Mol Catal A-Chem., 318(1-2), 75.

[5]. Govindaswamy. P., Sinha. C., Kollipara. M. R., (2005), "Syntheses and characterization of eta(5)cyclopentadienyl and eta(5)-indenyl ruthenium(II) complexes of arylazoimidazoles: The molecular structure of the complex [(eta(5)C5H5)Ru(PPh3)(C6H5-N=N-C3H3N2)]”, Organomet Chem., 690(14), 3465.

[6]. Shinar, J., (Ed.), Organic Light-Emitting Devices: A Survey, Springer-Verlag, NY, 2004.

[7]. Hens, A., Mondal, P., Rajak, K. K., (2015), "Synthesis, structure and photoluminescence properties of functionalized azoimine ligands and their nickel complexes”, Polyhedron, 85, 255.
[8]. Wang, J., Ha, C.-S., (2010), "Synthesis, structure and photoluminescence properties of functionalized azoimine ligands and their nickel complexes”, Tetrahedron, 66, 1846.

[9]. Cheng, Y.-F., Zhao, D.-T., Zhang, M., Liu, Z.-Q., Zhou, Y.-F., Shu, T.-M., Li, F.-Y., Yi, T., Huang, C.-H., (2006), “Azo 8-hydroxyquinoline benzoate as selective chromogenic chemosensor for $\mathrm{Hg}^{2+}$ and $\mathrm{Cu}^{2+»,}$, Tetrahedron Lett., 47, 6413.

[10]. A. Misra, M. Shahid, J. Phys. Chem., (2010), "Molecular Dynamics of Phycocyanobilin Binding Bacteriophytochromes: A Detailed Study of Structural and Dynamic Properties”, 114, 16726.

[11]. M. Kumar, J. Nagendra Babu, V. Bhalla, A. Dhir, (2009), Inorg. Chem. Commun., "Chromogenic sensing of $\mathrm{Cu}(\mathrm{II})$ by imino linked thiacalix[4]arene in mixed aqueous environment”, 12, 332.

[12]. Lou, X., Qin, J., Li, Z., (2009), "Colorimetric cyanide detection using an azobenzene acid in aqueous solutions”, Analyst, 134, 2071.

[13]. Arabahmadi, R., Orojloo, M., Amani, S., (2014), "Qualitative discrimination between organic and biodynamic Sangiovese red wines for authenticity”, Anal. Methods, 6, 7384.

[14]. Gunnlaugsson, T., Leonard, J. P., (2002), "Synthesis and evaluation of colorimetric chemosensors for monitoring sodium and potassium ions in the intracellular concentration range”, J. Chem. Soc., Perkin Trans., 2,1980.

[15]. Arabahmadi, R., Amani, S., (2013), "Synthesis and studies of selective chemosensors for anions and cations by azo-containing salicylaldiminebased receptors”, J. Coord. Chem. 66218.

[16]. İkiz, M., İspir, E., Aytar, E., Karabuğa, Ş., Aslantaş, M., Çelik, Ö., Ulusoy, M., (2015), "Chemical fixation of CO2 into Cyclic Carbonates by azo-containing Schiff Bases metal complexes”, New Journal of Chemistry, 39(10), 7786.

[17]. Odabasoglu M, Albayrak C, Ozkanca R, Aykan FZ, Lonecke P. Some polyhydroxy azoazomethine derivatives of salicylaldehyde: Synthesis, characterization, spectroscopic, molecular structure and antimicrobial activity studies. J Mol Struct. 2007;840(1-3):71-89.

[18]. Ceyhan, G., Köse, M., Tümer, M., McKee, V., (2012), "Novel polymeric potassium complex: Its synthesis, structural characterization, photoluminescence and electrochemical properties”, J of Lumin, 132(3), 850. 